„Bohemistyka” 2018, nr 2, ISSN 1642-9893

Małgorzata CIELICZKO

DOI: $10.14746 /$ bo.2018.2.3

Poznań

\section{„Being a dancer is not only a passion"1 - dance forms in the prose works of Milan Kundera}

All the misfortunes of mankind, all the dreadful disasters that fill the history books, the blunders of politicians and the lapses of great commanders, all this proceeds from not knowing how to dance...

Moliere, The Bourgeois Gentleman ${ }^{2}$ life. According to the author of this article, dance is used by Kundera to discover more interesting layers of the human condition, but much here depends on the reader.

Autorka artykułu bada, jak w prozie Milana Kundery funkcjonuje kategoria tańca oraz tancerza. Poprzedzona kulturoznawczym wstepem na temat figury homo saltans, analiza (fenomenologicznie rozumianego) tematu tańca przynosi cztery literackie obszary jego ujawniania się. Perspektywy te sa niesprzeczne, ale i niekomplementarne. Pierwsza nawiązuje do rytualnych tańców obrzędowych w kole, których (skrzywione) odbicie dostrzec można w społeczno-politycznym doświadczeniu XX wieku. Druga bada taniec jako element fabuły, który stawia pytania o własna istote, ma zatem charakter autoteliczny i uniwersalizujacy. Ujęcie trzecie pokazuje metaforyczne rozumienie ruchu tanecznego, czwarte zaś odnosi się do filozofii tańca i tancerza, którą zaproponował jeden z bohaterów Slowness (Powolność), wyprowadzając tę figurę z estetyki w kierunku doświadczenia życia publicznego. Według autorki taniec służy Kunderze odkrywaniu kolejnych, frapujących sfer kondycji ludzkiej, ale wiele zależy tu od czytelnika.

\section{A whirling prologue}

Homo saltans - the dancing human - is a figure, or rather a life practice, very well known to primeval human beings (probably) all over the world. Many researchers also believe that dance came about

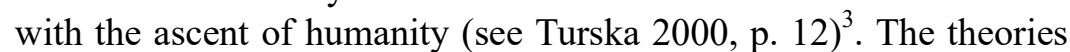
which attempt to find the genesis of dance are, however, quite varied, which is a result of the relatively late development of academic interest in this sphere of human existence - the first such research was not undertaken until the second half of the $19^{\text {th }}$ century. Many ethnolo-

\footnotetext{
${ }^{3}$ Jan Rey wrote about „musical pre-arts” which accompanied humanity since its beginning, and which was meant to involve dance, music and words (poetry): „The original human, wanting to discharge inner tension caused by joy or suffering, wanting to express his inner states, spoke, sang and danced at the same time" (Rey 1958, p. 11). Włodzimierz Tomaszewski, in writing about „triune choreia”, something typical of all the regions of the world: „Through a limited singularity of primitive movement-gesture, words and melodies, humans could display their humility towards mysterious nature, could approach it, to know it more intimately" (Tomaszewski 1991, p. 7).
}

${ }^{2}$ Source: http://www.personal.utulsa.edu/ john-powell/Vita/LeBourgeoisGentilhomme.doc [2018-01-05]. 
gists, anthropologists, cultural experts, sociologists and philosophers developed many theories, starting with the animalistic - drawn from the instinctive necessity of fulfilling biological (Herbert Spencer even went as far as trying to convince us that dance was a way of discharging ,excessive energies”) and existential needs. The dance moves motived by such impulses were to, in time, transform into unique cultural templates, since then serving a higher purpose: rituals, ceremonies, magic. Thus, dance was supposed to express the attitude of original humans to a surrounding reality which was often incomprehensible and rather frightening ${ }^{4}$. And yet there were also voices which located the source of dance movements in the human psyche, connecting rhythmical movements (individual and collective) with the desire to tear free of ordinary life, and therefore connecting primal dance with simplistic entertainment. Johann Huizinga, along with Théodule Ribot and Karl Gross, tried to argue that dance had always been something autonomous, independent of instincts, containing its own rules and creating its own world - it was a game, in a „Huizingaistic"meaning of the word (see Turska 2000, p. 15). Both concepts attracted many criticisms, and so more new theories were posited, such as those about the integrative aspect of dance which was supposed to finally socialise human beings (E. Durkheim, E. Grosse); there were also attempts to find a utilitarian connection between rhythmic movement and work which that movement was supposed to make more pleasant and quicker (K. Büchner); some found a vehicle for conveying inner feelings and emotions through gestures, movements and mimicry (K. Darwin), and even the first means of interpersonal communication - a motor language, using symbolics and being a sign of reflection of the outer world (S.K. Langer). More and more such concepts emerged, forcing researchers to abandon the search for one source of dance - it was Wilhelm Wundt in 1900 who would write about the existence of

\footnotetext{
${ }^{4}$ Alongside the aforementioned Herbert Spencer, similar theses were posited by James George Frazer and Bronisław Malinowski (see Turska 2000, p. 14; Lange 2009, pp. 29-30).
}

a double motive: subjective (dance as an expression of ecstatic feelings) and social (such as cult ceremonies) (Turska 2000, pp. 15-16; Lange 2009, pp. 31-35). Today, we are more able to see the development of dance movement from an even broader perspective and agree with Irena Turska that ,dance was born of the desire to satisfy life needs, of the willingness to discover reality, to externalise one's own attitude to it, the need to communicate and strengthen the sense of community" (Turska 2000, p. 16) ${ }^{5}$. This dance researcher does however note that we are still missing one remarkably important component - aesthetic value.

The lack of discourse about dance as an $\operatorname{art}^{6}$ is surprising, especially when we realise that it has lasted for some fifteen centuries ${ }^{7}$. The cause of this absence was the evident marginalisation of dance,

\footnotetext{
${ }^{5}$ Certainty involving the connection between dance and human beings, as well as the communities from which they emerge, has been around for centuries in various cultural circles around the world. This is characterised by the often-mentioned quote from Confucius: „Show me how a given nation dances, and I will tell you if its culture is healthy or sick". David Livingstone, a $19^{\text {th }}$ century discoverer and missionary, noted during his travels around Africa: ,.... a member of the Bantu tribe, when encountering a stranger, doesn't ask »Who are you? « but »What do you dance?«. This is because for residents of Africa the way they dance is shaped by their tribe, customs and beliefs, the mighty rhythms of a single community" (R. Garaudy, Dance of Life, trans. I. Turska, cit. by: Tomaszewski 1991, p. 89). Walter J. Ong shares this sentiment, writing: „Asked what he thought of a new village school principal, a Central African responded to Carrington [...], »Let's watch a little how he dances«" (Ong 2018, p. 54).

${ }^{6}$ Writing about discourse, I think of it in Foucaultian terms as a dynamic and scattered collection of not necessarily scientific statements of both a theorising and empirical character, but also taking into consideration social, causative and critical aspects. In the field of discourse, there is no room for encyclopaedic or didactic approaches, hence I do not take into consideration things such as textbooks teaching choreography and specific dance techniques, which have been published sporadically.

${ }^{7}$ During antiquity, two works were written on the theme: Dialogue about dance by Lucian of Samosata (or, according to some, it was Pseudo-Lucian) from the $2^{\text {nd }}$
} century as well as fragments of Feasting Sages by Athenaeus of Naucratis from the 
seen in Western culture at the time as either an element of religious ritual, which the Church in the Middle Ages (for political reasons) fought vigorously against (Lange 2009, pp. 17-19), or else as a form of entertainment for the nobility. It did not evolve alongside other art forms ${ }^{8}$, such as poetry or music, and it was only considered to belong to the world of high art as of the middle of the $18^{\text {th }}$ century ${ }^{9}$, although discussions about the correctness of such definitions lasted up until the $19^{\text {th }}$ century ${ }^{10}$. In $20^{\text {th }}$ century Europe more and more often people would indicate an approving, and often enthusiastic, approach to dance as an art form and to those performing it as unquestionably being artists. This correlated with trends of overcoming the taboos of physicality and leaving behind stereotypes connected with the body and gender. Dance too was thus freeing itself from formal con-

$3^{\text {rd }}$ century A.D., and then only in 1760 did the famous French reformer of dance, the ballet master Jean George Noverre publish his Letters about Dance and Ballet, which had a great influence on the development of dance arts. See Reiss 1951; Lange 2009, pp. 13-15, 22-23; Rey 1958, p. 27 and others; Dzikowski 1925, pp. 91-110).

${ }^{8}$ We also encounter theories that it was characterised by „reverse development”, seeing as in the period of early cultures dance was held up as the highest quality, while in ensuing centuries (at least until the 18th century) it not only did not evolve, but actually regressed. See Rey 1958, p. 14.

${ }^{9}$ We have to add that, for many centuries, the only dance form which qualified as an art form was performance which followed precise rules, meeting specific demands including classic criteria of beauty. Since the renaissance, right up until the $20^{\text {th }}$ century, the only art form involving dance was ballet (see Turska 2000, pp. 16-19). This represented an obvious echo of ancient aesthetics, seeing as it was Plato in his Laws who introduced a split between noble dance - ceremonial and beautiful - and one which was ritually-bacchanal, full of sensual fleshiness and abandon, something which definitely had to be rejected (see Lange 2009, pp. 14-16).

${ }^{10}$ And maybe also in the $20^{\text {th }}$ century, seeing as - and not without reason, I think Stanisław Dzikowski in his introduction to the 1925 study $O$ tańcu [On Dance] decided to stress: „The aim of this book is to turn the attention of our diverse public to the idea that dance is not just enjoyment, not only a way to discharge accumulated energy and one of the best way to flirt, but is an incredibly interesting social phenomenon, as well as being a serious branch of the arts" (Dzikowski 1925, p. 13). straints $^{11}$. This increase in prestige led to further affirmations of its various forms - as early as the second half of the $20^{\text {th }}$ century, theses began to appear which suggested that dance is not only an art form, but a way of life, of existence (see Garaudy, as cited in Tomaszewski 1991, p. 87). Tomaszewski, following on from many earlier researchers, also drew attention to the psychosomatic aspect which defined dance as an opportunity to ,enter the essence of dance which reconciles the body-spirit nature of human beings" (Tomaszewski 1991, p. 11); in other writings, he added:

Dance especially reminds us that art is above all the effect of human action - by which I mean movement. Art is a game played between the psyche and the physical. Those who dance are the ideal embodiments of such games (Tomaszewski 1991, p. 50).

It is likely that it always remained elusive, since its inherent refusal to allow itself to be shut up within simple frameworks, this dancing human - and along with them, dance or dance movement itself - became in recent decades an inspiration for many other art forms: painting, sculpture, visual performance; it was of course introduced into the sphere of literature ${ }^{12}$. The dynamically changing character of the European dimension of thought and culture in the $20^{\text {th }}$ century really did broaden the meaning and interpretative boundaries of this problem. More modern (and quite universal) metaphorical and even deeply philosophical elements were added to these mimetic and symbolic struggles, thus far sanctioned by centuries of tradition - in fact, semantic petrification of dance would have been a denial of its nature, which is constituted of movement, change, transformation and transgression.

\footnotetext{
${ }^{11}$ This happened as a result of intervention from key figures in modern dance, including Isadora Duncan, Ruth Saint-Denis and Ted Shawn.

${ }^{12}$ The problematics involving dance in literature have become the subject of many scientific conferences and volumes interpreting its various complexities; of the more important, Polish monographs on the subject we should mention: Kotliński 2016; Kulturowy obraz tańca 2012; Taniec $w$ literaturze... 2012; Taniec i literatura 2002; Pomarańska-Szumska 1999.
} 
Milan Kundera's prose provides researchers of literature with remarkable reference material. The writer, who happens to have musical training ${ }^{13}$, presents dance in a range of perspectives which are non-conflicting, and yet not characterised by complimentary qualities. I would like to point to four of the most well defined and troubling of these. The first relates to ritualistic dance rites whose (crooked) reflection can be found in the socio-political experience of the $20^{\text {th }}$ century. The second assumes direct use of dance motifs, which being an important component of narratives, also poses questions regarding its own identity, and therefore has an autotelic character. The opposing direction introduces a third angle - in which we are dealing with a metaphorical understanding of dance movement, adding meaningful context to events and characters in novels. And, last but not least, Kundera has dared to create a unique philosophy of dance and the dancer, having this figure emerge from experience aesthetically understood as art directed at public life. These four perspectives I will refer to as ,dimensions”- dimensions of dance in the prose penned by Milan Kundera.

\section{The first dimension: The Circle}

A weekly news magazine once ran a picture of a row of uniformed men shouldering guns and sporting helmets with Plexiglas visors. They are looking in the direction of a group of young people wearing T-shirts and jeans and holding hands and dancing in a circle before their eyes (BLF, p. 62).

The symbolic and integrating power of dancing in a circle meant it became one of the first, the most fundamental ,choreographies" of group dance overall. „Choreia was owned by the collective, was a circle of equals, bringing everyone together around the shared table or

\footnotetext{
${ }^{13}$ Which is often used in his texts, creating a more or less direct allusion to various musical works, or else describing and in some way explaining the world using musical notes recorded on the stave which he introduces into the realm of his text as its fully justified element.
}

the campfire" (Tomaszewski 1991, p. 26) - Tomaszewski observed. And so the dance circled some kind of important, shared centre - it could have been an arrow stuck in the ground ${ }^{14}$ or an altar, but above all those taking part in the dance became equal with regards to one another, which in medieval or baroque arts was best shown in danse macabre, which showed that when faced with death earthly disputes were mere trifles. Dancing in a circle survived for centuries, as evidenced by many ethnic dances, including those practiced today, from a range of cultural contexts around the globe. Interestingly enough, dancing in a ring today is a key element of choreotherapies.

The narrator suspects the group of young people in that photograph of a strong belief in the power of the dancing circle; faith - let us add which is rather naive. Nevertheless, a multilayered contrast between the armed, tightly lined up police officers and the improvising, Luddite, collective dance had to be stunning and remarkably photogenic. „Circle dancing is magic. It speaks to us through the millennia from the depths of human memory" (BLF, p. 63) - as noted by Kundera's fictional alter ego, referencing the desperate attempts by Professor Rafael, who at all costs wanted to join any sort of circle, even if it was antagonistic; just to dance in a circle and, holding the hands of other people, create some sort of union. A rather ironic comment is however disrupted by the honest confession:

I too once danced in a ring. It was in the spring of 1948. The Communists had just taken power in my country, the Socialist and Christian Democrat ministers had fled abroad, and I took other Communist students by the hand, I put my arms around their shoulders, and we took two steps in place, one step forward, lifted first one leg and then the other, and we did it just about every month, there being always something to celebrate, an anniversary here, a special event there [...]. Then one day I said something I would better have left unsaid. I was expelled from the Party and had to leave the circle (BLF, p. 65).

It is only the private experience of being relegated from a closedas it turns out - circle which made the protagonist aware of its truly

\footnotetext{
${ }^{14}$ See the report from Ceylon referred to by Curt Sachs, after: Rey 1958, p. 12.
} 
isolating and hermetic persona. In effect, there follows a complete overestimation of both ,choreographies"- the forced and violently charged (because of its connotation with fascist scuffles) line-up of uniformed men and the natural, organic, joyful circle of dancers would only be an illusion:

Leave a row and you can always go back to it. The row is an open formation. But once a circle closes, there is no return (BLF, p. 65).

Kundera over-interprets the traditional entanglements of dancing in a circle, showing its possible, real reversal - the Luddite naivety was easily exploited and in a subtle way began to carry very powerful, propagandist messages. The only thing which did not undergo change is the might of the circle, but it is politics which strips it of an honest, collective innocence. It is not possible to ignore this, being stuck in such a cursed circle - it may be that the dancers lack a broader perspective, or else they fall into a specific form of trance and, skipping about as if on air, elated, lifted by wings, they are no longer able to see anything other than the dance. For this is how we can interpret the eventual vision of the hero:

I realized with anguish in my heart that they were flying like birds and I was falling like a stone, that they had wings and I would never have any (BLF, p. 68).

The rock becomes here a symbol of solitary, hard stomping on the ground and sober, illusion-free existence among the „,winged" defenders of a new order, dancing to celebrate the hanging of more ,traitors of the nation", 15

15 This scene, which presents a group of young people, dancing in a circle, hovering over Prague as blindly believing in the ruling regime, was considered by David Lodge as an example of European magical realism. This narrative device was to be an answer to the idea of impossibility of describing difficult, complex historical narratives adequately - as well as the inner struggles connected with them using the language of traditional realism (see Lodge 1992, pp. 113-116).

\section{The second dimension: Erotica}

Dance for Kundera and his prose writing can also become a narrative element, which gives events their own unique rhythm, while not necessarily helping the plot along - sometimes, as in the case of erotic dances, it slows it down, building at the same time obvious tension. In such a direct way, stripped of additional meanings, we see it introduced into the story Symposium in the volume Laughable Loves (1970). Apart from complicating emotions, very much non-sexual, between the protagonists, the very act of dancing invites (the reader) to ask interesting questions relating to its genesis or character. The thing takes place in a doctor's surgery ,,in any odd department of any odd hospital in any odd town"during a session of nightly rounds, and the main characters are the nurse Alzhbeta, doctor Havel and a few other doctors:

When they both actually entered the staff room, Alzhbeta was standing in the middle of the room, twisting about horribly from the waist and emitting some singing sounds in a low voice. Dr. Havel looked at the floor, and the woman doctor, so as to relieve the shock of the two new arrivals, explained: „Alzhbeta is dancing.”

„She's a bit drunk,” added Havel.

"Alzhbeta didn't stop swaying her hips while gyrating the upper part of her body around the lowered head of the seated Havel.

„Wherever did you learn such a beautiful dance?” asked the chief physician. [...]

"I saw it at the striptease in Vienna," replied Alzhbeta.

„Now, now,” the chief physician scolded her gently. ,Since when do our nurses go to striptease shows?"

„I suppose it isn't forbidden, sir.” Alzhbeta gyrated the upper part of her body around the chief physician (LL, pp. 133-134).

Above all, we notice here the physicality ${ }^{16}$ of the female protagonist, which in the context of the dance she performs leads to the ques-

${ }^{16}$ The body of the dancer is an important aspect of deliberations on the subject of dance as a whole, because it represents the fundamental tool used in this art form. Lucian of Samosata (pp. 36-38) also wrote about the body of the person dancing; see also Turska, pp. 32-40; Byczkowska 2012; „Kultura Współczesna” 2011, no. 3: Ciało tańczace, ed. L. Bieszczad; Nowy taniec... 2012. 
tion about the sensuality and eroticism coded into it. The problem is much older and pronounced than striptease itself, which is a rather new dance form (starting around the end of the $19^{\text {th }}$ century), created solely for erotic entertainment. Firstly, it makes us consider cosmogony - the scene evokes Lucian's words, which try to convince that, the source of dance is eternal love, Eros" (Lucian of Samosata 1951, p. 15), but Eros is not just the Greek god of love and passion, but also the original, cosmic power which has been in existence since the beginning of the universe. It tends to refer to primeval cultures, in which dancing eroticism was connected with the cult of fertility. It is with the intervention of sensual movements that pleas were made for a plentiful offspring, as well as bountiful harvests; in the case of favourable response from the gods, as similar dance could also be performed in gratitude. It is worth recalling here the cult of Dionysus, which appeared in ancient Greece around the 6th century B.C. and quickly grew to match the influence of the cult of Apollo. Dionysus was associated more with human carnality and sensuality than reason, allowing liberation from daily restrictions, a forgetting of the self, lack of contemplation through ecstatic, whirling craziness ${ }^{17}$ - these were supposed to allow an entry point to different states of perception, to engaging with that which could not be known or expressed (see Tomaszewski 1991, p. 12-15) ${ }^{18}$. Nevertheless, festivals celebrating

${ }^{17}$ This was a kind of dance which was definitely rejected and belittled by Plato and the proponents (which included Lucian) of the dual separation of ceremonial and wild dance - the latter, Bacchanalian-sensual was not, according to the philosopher, fit for „civilised” citizens (see Lange, p. 15).

${ }^{18}$ Maurice Béjart - a world class dancer and choreographer from France - wrote about two specific aspects of dance: secular and religious. While the first creates a collective identity and allows a sense of unity with the group (as in the case of the „circle"), the other has a very different, metaphysical character, and human beings, as individuals, become lonely in the face of Mystery, the Unknowable. „Words don't serve anything. Why call this God, the Absolute, Nature, Accident? ... All that is needed is to make contact. That which human beings seek beyond understanding is communication. Dance is born of the need to say the inexpressible, to know the the god of wine were also connected with vegetarian cults ${ }^{19}$. The eroticism of Alzhbeta as she dances is therefore to be understood in a context wider than that of a formally inappropriate performance, delivered in an alcohol-fuelled haze, as it appears to be to the other protagonists. It is not hard here to spot a contemporary element alluding to the cult of fertility (highlighting the female hips and breasts supports this theory), eminently involved in the sense of living, but also a powerful gesture of liberation from cramped social norms which the individual is forced to endure. These are contemporary Dionysia - celebrated in the book (probably intentionally) with a bottle of wine. The universal character of Alzhbeta's exhibitionist performance is enhanced by the ill-defined nature of its setting - it could have taken place just about anywhere. The scene, however, encourages us to ask questions not only about the nature of human beings, but also about dance.

Alzhbeta went on dancing, but her audience was probably far worse than the one at the Vienna strip joint: Havel lowered his head, the woman doctor watched scornfully, Flaishman negatively, and the chief physician with fatherly forbearance. And Alzhbeta's backside, covered with the white material of a nurse's apron, circled around the room like a beautifully round sun, but an extinct and dead sun (wrapped up in a white shroud), a sun doomed to pitiful redundancy by the indifferent and distracted eyes of the doctors present. [...]

„You should quit, Alzhbeta," said Havel in the direction of the floor.

„quit?” said Alzhbeta. „After all, I'm dancing for your sake. And now I'll perform a striptease for you! A great striptease!" and she undid her apron, and with a dancing movement cast it onto the desk (LL, pp. 134-135).

Dancers need an audience - according to the quoted extract - because without a positively responsive public the whole performance becomes pitiful and „useless ”. The dancer solves the problem with her audience in two ways: first, she specifically dedicated her dance to

unknowable" - according to Béjart (cited in: Tomaszewski 1991, p. 98).

${ }^{19}$ And so at this time: „Agraulids, Chariots and Nymphs danced to the rhythm of the pastoral melodies of Hermes or the Lord, which could successfully be played by winds in the reeds, and their dance caused the plants to sprout, fed on dew, bloomed, bore fruit" (Zwolski 1978, p. 140). 
Dr Havel, wanting to appeal to him and attract his interest (or maybe she only was only teasing him, as a femme fatale, about his shyness as expressed by his permanently lowered gaze?); the rest of those watching might as well not have been there for her. She acted out a quasistriptease, because apart from her apron she did not remove any other items of clothing - and yet, her dance was convincing enough to fool the other men, towards whom she ,threw" her imaginary clothes and undergarments, into taking up the role-play, pretending to be catching them with their hands. And yet towards the end of the performance, Alzhbeta began to lose interest in the - already engaged - men and began to dance for herself, observing and sensing her own moving body:

Then she stood on her tiptoes again, posing in the full glory of her fictional nakedness. She was no longer looking at anyone, not even at Havel, but with the halfclosed eyes of her half-turned head she was staring down at her own twisting body (LL, p. 137).

This analogous look within herself during an erotic dance performance (only now as a true striptease performed for a lover) is something experienced by a different Kundera heroine - Eva from The Book of Laughter and Forgetting:

Eva twisted her body into various dance movements, discarding clothing piece by piece as she went. Never once the whole time did she so much as look up at Karel. She concentrated completely on herself and her movements [...] (BLF, p. 35).

Both women at some point focus their attention onto their own bodies, their own motor functions and psycho-physical sensations; they get lost in themselves - becoming dancers and the audience at the same time, forgetting about the reality which surrounds them. They are amateurs, who spontaneously, feeling the need of the moment, begin their unprofessional performance ,for someone" yet - completely surrendering to the power of dance moves - they complete it ,for themselves". Their behaviour is surprisingly convergent with Władysław Witwicki's deliberations recorded in his work $O$ naturze tańca [On the nature of dance]:
When discussing dance as being essentially a visual performance, we do not only mean externally, but also internally. This means, first of all, that people mostly like to watch those who dance and in turn those who dance try to move in a way which makes the look beautiful on the surface. Even if they do not think about their audience and do not care about them at all. This means, secondly, that one can dance without an audience, alone, just for oneself, $[\ldots]$ this is when the dancer $[\ldots]$ surrenders to an inner viewing of their own performed moves (as cited in: Tomaszewski 1991, p. 81).

Dance without an external audience is not only possible, but it seems likely to be more satisfying than that performed in the face of a public which reacts with embarrassment, irony, disapprobation or even condescension. But is the dancer really able to free themselves from the audience (regardless of whether they are a professional or an amateur)? Or expanding the question: is a human being - as homo theatralis - in any way able to forget, even for a second, that they are watched, that they constantly find themselves dancing on the stage of life? Or maybe we have to accept the fact that someone is always watching us and the awareness of this is always with us even if from time to time we try to disregard it. Because even the act of complete focus on the self, as in the case of Alzhbeta and Eva, doesn't of course mean the annihilation of the audience, but rather its transformation the inner self becoming the audience.

Of course, none of these questions have been explicitly asked in the quoted scene - a scene which appears to be quite simple and stripped of deeper sense... And yet, much here depends on the „viewer”. Will the reader treat Alzhbeta condescendingly? Or the opposite - will they allow important problems to exist, problems which are revealed by the liberated act of moving? The desire to „dance behind that stage" and perceive the theoretical and philosophical potential seems to be irresistible.

\section{The third dimension: Entangled Waltz}

In The Farewell Waltz (1976) no one dances, no one ever mentions it in conversation and in fact the title of the novel presents us with an engaging problem. Dance here has been introduced purely as a meta- 
phor - it is the fates, emotions, experiences, hopes and shared relations felt by the protagonists which exist in a relentless, mutually animating movement: „they entangle in a whirling frolic, floating as if it were a waltz with a continually rising tempo", according to the jacket notes of the Polish edition (see WP).

Following this idea - apart from the basic step, hence subsequent elements of a (surprisingly ordered) narrative - one can also observe turns or Natural and Reverse Fleckerls ${ }^{20}$; in the case of the novel, these will be all the intrigues, lies, mutual rejections and approaches, manipulations and ecstatically displayed emotions, the otherness of adopted perspectives, and finally (usually subtle) return to the starting point. Everything has, however, been precisely composed and maintained in an even tempo, something Kundera himself emphasised when writing that this novel, is absolutely homogeneous, without digressions, on a single subject, narrated at the same tempo throughout, very theatrical, stylized, its structure drawn from farce [vaudeville M.C.]" (DAC, p. 93).

And so: vaudeville or waltz? If the former, then why the latter? And why is it ,farewell”? Such questions have thus far not been asked by those analysing the novel ${ }^{21}$, pointing to Kundera's own comments, without noticing (the significance) of this dissonance. It is not hard to agree with Kundera who talks about the vaudevillian nature of this work, but we must remember that the accumulation of improbabilities and exaggerations in a writer of this caliber has to be an intentional decision, conscious and meaningful, and so they cannot be assigned to,

${ }^{20}$ One of the basic structures of the Viennese waltz involves the making of several correctly entangled steps, performed - thereby making it unique - in the centre of the dance floor, in one spot, which in effect allows pairs to make a unique turn.

${ }^{21}$ It is worth adding a side note about how these sorts of question could not be asked for over two decades by readers of the English language version, because the 1976 translation by Peter Kussi - a Czech (!) translator - was titled The Farewell Party. It was not until a new translation in 1998 by Aaron Asher, adapted from the French version, which Kundera had corrected, had the title The Farewell Waltz. say, an author with a middling skillset ${ }^{22}$. Researchers labelled The Farewell Waltz a „buffo opera” (H. Kosková) or else pièce bien faîte (Illg 1992, p. 89), staying with the sphere of the so-called ,boulevard theatre", scenic and musical, operating using characteristic characters and a fast-moving narrative. And so why the waltz? History tells us that it was once a suburban dance, performed in cheaper venues, and its introduction into classier salons resulted in numerous society scandals. Today, two kinds of waltz are included in the list of (a mere five!) standard dances, performed during ballroom dance tournaments around the globe. There is a certain innate contradiction contained in both Kundera's novel and waltz itself. The book attains that which the author terms his biggest ambition, both artistic and existential:

[...] the connection of the highest form of gravitas with the greatest possible lightness of form"(DAC, p. 86).

The desire for love, jealous, sexuality, chaotic feelings, freedom and slavery (emotional and political), emigration, (in)fertility, abortion, motherhood, fatherhood, Christianity, God, murder, death - this is only a sample of the topics covered in the novel. Vaudeville? Yes, because the story - decidedly forcing its way into the foreground - is indeed uniform, theatricalised, delivered very effectively, and yet incredibly exaggerated. The waltz? Sure, seeing as those rhythmic movements delight, linking the individual scenes into a logical and cohesive hole, impossible to arrive at anywhere but in an artistic space. In this waltz, however, there is no fluidity which is essential to it there are too many insinuations and misunderstandings ${ }^{23}$, asymmetric thoughts, spontaneity (actions/omissions), while disturbances are no

\footnotetext{
${ }^{22}$ Ewa Graczyk, although she does not share this opinion, agrees that some readers might interpret The Farewell Waltz in this way, and she looks for causes in the experimental character of the novel, which was compared by the author to a „literary product of average quality” (Graczyk 1994, pp. 34-35).

${ }^{23}$ Jacek Illg wrote, among other things, about the blurred differences between the literal and metaphorical meaning of words, about disassociations of expression and content, or else the gap between matter and spirit (Illg 1992, pp. 150-154).
} 
longer designed figures, beginning to more and more remind us of uncontrolled, fatalistic chaos. Movement towards the absurd and/or destruction cannot escape the readers attention. Maybe this is why the title clarifies that this is a ,farewell" waltz, and therefore connected with a break, stoppage or specifically with an (ambiguous) end, which is present not only in the final moment, constantly accompanying the protagonists of this ironic, and yet involving and ruthless, novel. Roman Zimand noticed that the desire for geometric composition has been perfected here (the critic commented on the plot, which resembles an algebraic equation, as well as the rigidly formed relations between the heroes), seeing in this an influence of $18^{\text {th }}$ century novel traditions, but from the narrative alone - the researcher added - comes the thesis about a defined lack of clarity when it comes to human gestures or relations. „The final result of our actions is different to our aims and specific plans, things Kundera's protagonists delight in" (R.Z. 1984, p. 175) - he added. The separation between the intentions and the actual effects of protagonists' actions, as well as the more elevated - between the order of the (almost geometric) composition and the narrative ambiguity and illegibility of the world - can perhaps be key to understanding why this waltz turns out to be final/farewell. The negation of predictability and order, even if only in the dancing composition of the waltz (so firmly fixed in our culture), is the act of essentially doubting whether the world is, on the whole, knowable. The fissure which forms then destroys the dance's fluidity (synecdoche of life harmony?), condemning it to entanglement, and therefore symbolic death.

\section{The fourth dimension: (moral) Judo}

One more specifically characteristic and original development of a problem connected with dance makes an appearance in Kundera's Slowness (1995) - the figure of the dancer. The author of this concept in the novel is Pontevin, and his words:
That obsession with seeing his own life as containing the stuff of art is where you find the true essence of the dancer; he doesn't preach morality, he dances it! (S, p. 17)

could be considered to be an excerpt of a theoretical-philosophical essay on dance. They could be, if it wasn't for the mention of morality rather surprising in this context. Pontevin happens to be an insightful observer of human interactions. He is, by profession, a doctor of literary theory, ,sitting bored in his office at the Bibliothèque Nationale" (S, p. 22), but during social encounters he talks on, constructing conceptions regarding human interactions, and not art sensu stricto, of which the most important is:

All politicians nowadays, Pontevin says, have a bit of the dancer in them [...]. The dancer differs from the politician in that he seeks not power but glory; his desire is not to impose this or that social scheme oil the world (he couldn't care less about that) but to take over the stage so as to beam forth his self. Taking over the stage requires keeping other people off it. Which supposes special battle tactics. The battle the dancer fights, Pontevin calls ,moral judo"; the dancer throws down the gauntlet to the whole world: who can appear more moral (more courageous, more decent, more sincere, more self-sacrificing, more truthful) than he? And he utilizes every hold that lets him put the other person in a morally inferior situation (S, pp. 18-19).

Analysis of many years of efforts in the political-social arena made by the politician Duberques and intellectual Berck, whom he described as the ,martyr-king of the dancers" gave the hero the ability to develop his thoughts.

If a dancer does get the opportunity to enter the political game, he will showily refuse all secret deals (which have always been the playing field of real politics) while denouncing them as deceitful, dishonest, hypocritical, dirty; he will lay out his own proposals publicly, up on a platform, singing and dancing, and will call on the others by name to do the same; I stress: not quietly (which would give the other person the time to consider, to discuss counterproposals) but publicly, and if possible by surprise: „Are you prepared right now (as I am) to give up your April salary for the sake of the children of Somalia?" Taken by surprise, people have only two choices: either refuse and discredit themselves as enemies of children, or else say „yes” with terrific uneasiness, which the camera is sure to display maliciously (S, pp. 19-20).

The concept of the politician-dancer, which is very much on point and full of bitter perception, treats dance in a very different way - nei- 
ther literally, nor metaphorically. It rather exploits it, referring to it rather objectively and treating it arbitrarily. That this is not just the effect of unique poetic licence can be seen in the words from the aforequoted theoretician of dance, who notes:

[...] dance is not just physical work done by the body, but a specific quality, different to typical corporeal mechanics. And so we have to assume that dance can be treated subjectively and objectively: as the narrative of our lives or as an object, goods traded in a game (political, economic, social). At the same time, because dance cannot be separated from the dancer, objective attitudes to dance imply an objective approach to human beings (Tomaszewski 1991, p. 15).

Pontevin's dance - with his figures aimed at surprising the opponent or making each discussion and proposal public - represents a key element of the political game played by a specific kind of public persona. Dance, of course, all by itself does not appear here as readymade „goods", but serves to construct (as a unique form of analogy) concepts in which „to dance" suggests a lot more than moving the body in a beautiful and rhythmic way. From here on in, it begins to mean more or less as much as: in an equivalent, „scenic” way present certain ideas to a broader public, which is meant to create an effect directed towards change. In this way, dance in Kundera's writing has taken on a performative effect, while the dancer-politician is an active and dynamic figure, one which uses actions to effect certain changes in the surrounding reality - by becoming a performer ${ }^{24}$. The intended

${ }^{24}$ I am referring here to, among other things, to performativeness as defined by Ewa Domańska in terms of a specific kind of agency. She indicates a dualistic origin of this phenomenon: Austin's theory of acts of speech (in short: language does not only present reality, but it also causes changes in it) as well as the mystery of playing out, the theatricality of the performative act, meaning the performance. Jacek Wachowski adds that it is this second source which is foremost for the majority of researchers of this field, hence the frequent association between the performative and the acting body - performativity then appears to be a general category, of a cultural nature. And yet we mustn't forget about philosophical and linguistic complications, according to Wachowski, seeing as these allow us to focus our attention on actions which bring about permanent effects and it is they which effect is achieved through engagement, demonstrative actions, meaning a unique performance, finely fitting the definition of that ostentatious question, posed before rolling cameras - and therefore public about surrendering his income in the name of starving children. In fact, it is not the aim of his actions which matters here (be it hidden or official), but the point is that some form of overestimation is taking place, something - because of his actions! - is changing. Not necessarily in an ethical, rather in a factual way.

The theme of dance, used so freely, in no way devalues the essence of the action itself, quite the opposite - it reveals how rich and fruitful in terms of meaning its character is, how liberally it opens to completely new spheres of existence, allowing them to be experienced in better, more detailed and interesting ways. We cannot in this case talk about any sort of deprecation also because the same figure of Kundera's dancer is free of any pejorative connotations; elsewhere, Pontevin adds:

[...] Anyone who dislikes dancers and wants to denigrate them is always going to come up against an insuperable obstacle: their decency; because with his constant exposure to the public, the dancer condemns himself to being irreproachable; he hasn't made a pact with the Devil like Faust, he's made one with the Angel: he seeks to make his life a work of art, and that's the job the Angel helps him with; because don't forget,

will represent performative acts, as opposed to those which are non-performative, and whose effects can be reversed. And yet, there are certain proposals to call both acts performative, as in the example of Marco De Marinis, following on from Richard Schechner, who writes about „transformative performance” (leading to permanent change) and ,transportational performance” (leading to temporary change). The sketched-out panorama of the problem presents performance, which in a narrow sense means delivery in the presence of an audience of actions which had a theatrical/scenic character, such as a happening, while in a broader sense it is understood as every day practice in social life which appears in rituals, demonstrations or parades. The perspective we adopt depends on whether we refute the performativeness of these actions, whose effects are at most temporary. Kundera's concept of the dancer assumes the irreversible causality of its actions, and so we can firmly see in it a unique performer. See Domańska 2007, Wachowski 2015, De Marinis 2013. 
dancing is an art! That obsession with seeing his own life as containing the stuff of art is where you find the true essence of the dancer; he doesn't preach morality, he dances it! (S, pp. 21-22).

It is hard here not to feel a subtle sense of irony, or else maybe only the author giving us a wink and a nudge, which happens to accompany the figure of Pontevin from the very start:

The dancer concept is known only to a small circle of Pontevin's friends. It is his great invention, and perhaps regrettably, he never developed it into a book or made it a subject for international symposia (S, p. 18).

Further on, the protagonist has been characterised as one of the great students of Epicurus, who, ,invents and develops his ideas simply because it gives him pleasure. He does not despise mankind, which is for him an inexhaustible source of merrily malicious reflections, but he feels not the faintest desire to come into too close contact with it. He is surrounded by a gang of cronies who get together at the Café Gascon, and this little sample of mankind is enough for him" (S, p. 23). The ironic, though not stripped of sympathy, way of constructing this character in no way undermines the sense of the concept in itself - meanwhile, it shows the dissonance between its subject and object. While the dancer wants to win at moral judo and occupy the stage a little longer, Pontevin's thought follows a different path:

A person who makes his ideas public does risk persuading others of his viewpoint, influencing them, and thus winding up in the role of those who aspire to change the world. Change the world! In Pontevin's view, what a monstrous goal! Not because the world is so admirable as it is but because any change leads inevitably to something worse (S, pp. 22-23).

His friend Vincent suggests that its declared and real positions are in opposition to one another, and hence the conception has overwhelmed (because it has absorbed) its author. Any time an attractive woman appeared nearby, Pontevin instantly became a textbook exemplification of his own idea - wanting at all costs to draw attention to himself, even if it meant moving his friends aside or even ridiculing them. If we agree with the afore-quoted words that ,the dance cannot be separated from the dancer" and hence the „objective attitudes to dance imply an objective approach to human beings" then Pontevin is a wonderful representation of this. Such an approach is typical of the dancers being described - seeing as their actions, usually noble in character, are in fact designed for a self-centred purpose, and hence the empathy which has been achieved through the dance, along with other people, are only a means to a selfish end. And so the question appears - can human beings ever not-be this kind of dancer, seeing as this conception has universalising tendencies. Pontevin tried to defend against a rather justified accusation, explaining that his conception only applies to ,exhibitionists in public life” (S, p. 26), and does not apply to interpersonal encounters. This is a doubtful separation, if not in fact artificial. Perhaps we are all dancing - on a smaller or larger stage, more or less skilfully.

\section{A dancing epilogue, or else a bow}

The pages of the novels by Milan Kundera turn out to be a remarkable stage for dancers and dance itself. This seems to be so prevalent that it could be considered one of the key themes in his work, and yet it features in such a subtle and un-obvious way (sometimes by accident, sometimes rather ordinarily, but also ostentatiously and at times imperceptibly) that it first has to be noticed/noted, and then extracted and interpreted. It seems truly characteristic and possibly most interesting that Kundera makes wonderful use of dancing as well as the borders it sets (mostly theoretical) - borders which the author obviously then immediately breaches. He counterpoints theories about dance as a social phenomenon by pointing to the loneliness of the dancer: the writer juxtaposes the seeing of mystical experiences in dance with political aspects; convictions that dance is a physical and spiritual experience are contrasted with intellectual processes, etc.. The dance here seems to evade... the dance.

It is hard to firmly conclude whether it was the writer who „danced" with this mobile and artistic theme, or whether it was the 
theme which broke free and began to take on a life of its own - perhaps even developing its own choreography. The number of perspectives which are in no way limited to the four indicated dimensions, and which weave dance into various life and historical spheres - enrich both the problematics of dance as well as adding key meanings to the texts themselves. What else is there for the reader to do? Get carried away in a banal dance? Or maybe became a dancer-performer, as described by Grotowski:

A Performer - with a capital $\mathrm{P}$ - is a person of action. Not someone who plays someone else. They are the dancer, the priest, the warrior (Grotowski 1990, p. 214),

while also being - if I can add in the way of extrapolation - courageous interpreters of the work, in terms of literary theory.

Translated by Marek Kazmierski

\section{Source shortcuts}

BLF M. Kundera, The Book of Laughter and Forgetting, trans. M.H. Heim, Penguin Books, Great Britain, 1983.

DAC M. Kundera, Dialogue on the Art of Composition, interview conducted by C. Salmon, in: M. Kundera, The Art of the Novel, trans. L. Asher, Faber and Faber, Great Britain, 1990.

LL M. Kundera, Laughable Loves, trans. S. Rappaport, Faber and Faber, Great Britain, 1991

S M. Kundera, Slowness, trans. L. Asher, Harper Perennial, NY USA, 1997.

WP M. Kundera, Walc pożegnalny, trans. P. Godlewski, Warszawa 1990.

\section{References}

B é j a r t M., 1991, Przedmowa do ksiązki Rogera Garaudy »Taniec życia«, trans. K. Stefaniak, in: W. Tomaszewski, Człowiek tańczacy, Warszawa.

B y c zk ow sk a D., 2012, Ciało w tańcu: analiza socjologiczna, Łódź.

D e M a rin is M.,2013, Performans i teatr. Od aktora do performera i z powrotem?, trans. E. Bal, in: Performans, performatywność, performer. Próby definicji i analizy krytyczne, ed. E. Bal, W. Świątkowska, Kraków.

Domańska E., 2007, „Zwrot performatywny» we wspótczesnej humanistyce, „Teksty Drugie”, no. 5

D z i k ow s k i S., 1925, O tańcu. Rozważania kulturalno-obyczajowe, Warszawa.
G a r a u d y R., 1991, Taniec życia, trans. I. Turska, in: W. Tomaszewski, Człowiek tańczący, Warszawa.

Gra czy k E., 1994, O Gombrowiczu, Kunderze, Grassie i innych ważnych sprawach, Gdańsk.

G r o t ow sk i J., 1990, Performer, in: idem, Teksty z lat 1965-1969, selected and edited by J. Degler, Z. Osiński, Wrocław.

I 11 g J., 1992, W kręgu powieści Milana Kundery, Kraków.

K o tl i ń s k i A., 2016, Tańce polskie: suita historycznoliteracka, Olsztyn.

„Kultura Współczesna” 2011, no. 3: Ciało tańczace, ed. L. Bieszczad.

Kulturowy obraz tańca, 2012, ed. J. Bujak-Lechowicz, Szczecin.

L a ng e R., 2009, O istocie tańca i jego przejawach w kulturze. Perspektywa antropologiczna, Poznań.

L o d g e D., 1992, The Art of Fiction, Penguin Books USA.

L u c i a n of S a m o s a ta, 1951, Dialog o tańcu, trans. J.W. Reiss, Warszawa.

Nowy taniec. Rewolucje ciała, 2012, ed. W. Mrozek, Warszawa.

Ong W.J., 2002, Orality and Literacy: The Technologizing of the Word. Online: $\mathrm{http} / / / \mathrm{dss}$-edit.com/prof-anon/sound/library/Ong_orality_and_literacy.pdf.

P o marán ska-S z u m ska A., 1999, Jak tańczy wspótczesna poezja? Taniec jako tworzywo i forma wiersza, ed. E. Czaplejewicz, Warszawa.

R e i s s J.W., 1951, Wstęp, in: Lukian z Samosate, Dialog o tańcu, trans. J.W. Reiss, Warszawa.

R e y J., 1958, Taniec. Jego rozwój i formy, trans. I. Turska, Warszawa.

R.Z. [R. Zimand], 1984, Ten cholerny Kundera, „Almanach Humanistyczny”, no. $1-2$.

Taniec i literatura, 2002, red. E. Czaplejewicz, J. Potkański, Warszawa.

Taniec w literaturze polskiej XIX i XX wieku, 2012, ed. S. Karpowicz-Słowikowska, E. Mikiciuk, Gdańsk.

To m a s z e w s k i W., 1991, Człowiek tańczacy, Warszawa.

T u r s k a I., 2000, Spotkanie ze sztuka tańca, Kraków.

W a c h o w s k i J., 2015, Ciało performatywne, „Przestrzenie Teorii”, no. 23.

W it w i ck i W., 1991, O naturze tańca, in: W. Tomaszewski, Człowiek tańczacy, Warszawa.

Z w o 1 s k i E., 1978, Choreia. Muza i bóstwo w religii greckiej, Warszawa 1978. 